\title{
Estimating the Optimal Level of Public Debt for Economic Growth: An Evidence from Pakistan
}

\author{
Muhammad Ashfaq ${ }^{1}$ and Ihtsham Ul Haq Padda ${ }^{2^{*}}$
}

1 Lecturer, Government Inter College, Panjera

2 Head, Department of Economics, Federal Urdu University of Arts, Science and Technology, Islamabad Corresponding Author (ihtsham91@yahoo.com)

Received:O2 Nov, 2019

Revised: 13 Dec, 2019

Accepted: $27 \mathrm{Dec}, 2019$

Published: 28 Jan, 2020

How to cite this paper: Ashfaq, M., Padda, I. U. H. (2019). Estimating the optimal level of public debt for economic growth: An evidence from Pakistan. Quest Journal of Management and Social Sciences, 1(2), 222-232.

Copyright (C) 2019 by authors and Quest Journal of Management and Social Sciences

This work is licensed under a Creative Commons Attribution-NonCommercial-NoDerivatives 4.0 International License.

https://creativecommons.org/licenses/ by-nc-nd/4.0/

\begin{abstract}
Background: In underdeveloped economies, the role of public debt is very vital with the intention of achieving a desirable level of output, employment and sustainability in long run economic growth. Fiscal deficit in developing economies is a common phenomenon because of low tax base and high imports. Economy of Pakistan is also facing fiscal deficit and trade deficit since its independence, so it relies on public debt to fill this fiscal gap.
\end{abstract}

Objective: The objective of this study is to estimate the optimal level of public debt for economic growth.

Methods: This study explores the nonlinear relationships between public debt and economic growth of Pakistan by using time series data. The ARDL bound test technique is used to estimate the short-run and long-run impact of debt on economic growth. The growth maximizing level of debt is also estimated.

Results: According to the estimated parameters, the optimal level of public debt is $60 \%$ of GDP. It also indicates that increase in government borrowings will raise economic growth in Pakistan in the long run. However, in the short run, if public debt increases it will boost economic growth after some levels of public debt and it will start declining.

Conclusions: This study implies that public debt must be discouraged beyond optimal level of debt, as above optimal level it adversely affects the economic growth.

Implications: The implication of the findings of the study is that higher interest rate curbs economic growth, therefore, present policy of keeping high interest rate by government should be revisited.

Recommendations: Government of Pakistan should focus on fiscal and current account deficit, which are the main cause of increasing public debt, because higher public debt is not good for economic growth. Also, suitable fiscal policy is needed to control the debt burden and to get rid-off Ponzi game of debt from Pakistan by strictly enforcing the Fiscal Responsibility and Debt Limitation Act 2005.

Keywords: Developing economies, Economic growth, GDP, Pakistan, Public debt, Originality: This paper is original and has not been published in other publications. No financial support has been received while working on this paper.

Paper Type: Research paper

JEL Classification: E01, E44, F62, F63, N15 


\section{Introduction}

Economic growth is imperative for developing economies to attain sustainable development in the long run. The developing countries are facing various challenges like fiscal deficit, trade deficit, low saving to investment ratio, and low economic growth etc. Economic growth is required to control their fiscal deficit; moreover, developing countries attempt to reduce fiscal deficit through managing public expenditures, revenues and taxation. Public debt plays a vital role to remove fiscal deficit, and increasing investment of developing countries like Pakistan. For improvement in per capita income, improvement in economic growth is an important precondition. Therefore, investment is required to bring improvement in economic growth. Governments finance their budget deficits through various sources; for example, generating revenues through tax collection, printing new money, domestic and foreign borrowing and using previous budget surplus. If public debt is utilized through proper management, it clearly brings prosperity. But when it is used imprudently and in an uneconomical way, it affects the economy in an opposite direction. Excessive debt trap reduces the economy's ability to distribute the important services to its residents. Public debt is not considered a good weapon to boost the economy until its proper utilization; however, it is coupled with ground realities and growth theories that it can bring prosperity and economic development by providing the additional resources (Gul, 2008; Haris \& Mohammad, 2015).

The importance of public debt has become very crucial for economic growth, mostly, where governments face increasing fiscal deficits. Classical theory suggests that public debt is a burden to future generations and in the long term debt drags the investment, similarly, Ricardian theory recommends that public debt is same as future tax (Barro, 1979). On the contrary, Keynesian argument is that government borrowing plays the role of encouraging, in the short run, a reasonable stock of public debt. Antonio and Joao (2012) depict that due to high debt, the future tax will increase, so consumption will be reduced and resulting into a lower investment and employment opportunities. Elmendorf (1999) examined that when the output is far from capacity, the positive effect of higher debt may be large on economy. Neoclassical economists like Modigliani (1961), Dimond (1965) and after that Saint-Paul (1992) have argued that if public debt is increasing, in the long run, it will have negative effects on GDP growth as stated in the study of Antonio and Joao (2012). Dimond (1965) argued that when a government has a budget deficit it will borrow from domestic resources and use domestic private saving. Moreover, it leads to low opportunities for private investors and private investment demand declines. The final situation will be reduction in GDP growth and development. If debt financing is done properly it brings higher economic growth and increases the capacity to debt servicing. Rosemary (1993) argued that government borrowing negatively influenced the GDP growth. The adverse effects of public debt are channeled thorough debt overhang ${ }^{1}$ and crowding out (Akram, 2011).

Public debt is attained from domestic and foreign institutions. A moderate amount of foreign debt may be able to enhance GDP by the way of capital formation and factor productivity (Chaudhary, 2001). Internal sources affect economy through inflation and interest rate and ex-

Debt overhang is a situation, in which an economy is unable to repay its debt. 
ternal sources affect through exchange rate, so borrowing from external sources creates macroeconomic stability through productive investment (Burnside and Rebelo, 2001). Most of the advanced economies nowadays rely on borrowing rather than seignorage to finance its fiscal deficit.

In this context, Simon and Carmine (2016) have found that higher burden of external debt negatively affects investment, which finally impacts GPD growth in long run. Safdar and Padda (2017) and Catherine et al. (2004) also suggest that high external debt would lead to low total factor productivity. Antonio and Joao (2012) have found that high debt eases total factor productivity. Issue of government debt levels, economic growth and total factor productivity growth are complicated and have various features. In recent decades, growth and productivity are the most crucial factors for macroeconomic stability. Thus, the relationships between the debt levels, economic growth have concerned attention of economists. Most of the studies in literature have estimated only linear association between government borrowing and GDP growth. In context to previous discussions, present study aims to find out optimal level of public debt for Pakistan using ARDL technique for the period of 1973-2018. The findings of this study will enhance our understanding about public borrowing and GDP growth.

\section{Overview of public debt in Pakistan}

Historically the public debt of Pakistan averaged 69.5\% of GDP from 1973 to 2018, reaching as high as $102 \%$ of GDP in 2001. Economy of Pakistan has experienced on average 6.5\% fiscal deficit of GDP. Due to high fiscal deficit, the government has relayed on public debt that is indicated in graph1. The government decided to make a debt reduction strategy in early 2000, to bring this huge amount of public debt on a sustainable level. As a result of the policy, public debt level sharply declined to $57 \%$ by 2007 . Moreover, reduction in fiscal deficit and trade deficit brings stability in exchange rate, and plays a key role in reducing public debt burden on country.

During 2000-2015, public debt of Pakistan increased by $12.6 \%$ per year. If we look into it more profoundly, we can find that public debt has grown on average $6.9 \%$ per annum, during the period of 2000 to 2007. This is due to lower fiscal deficit and stability in exchange rate as well. Public debt slightly declined more during 2007-10, after that it again reached $60 \%$ of GDP. Fiscal deficit was recorded 8.2\% of GDP during 2013, against the estimated budget of $4.7 \%$ of GDP. The prevailing persistent budget deficit has enhanced public debt. Graph 1: Trends in fiscal balance and public debt in Pakistan (\% of GDP)

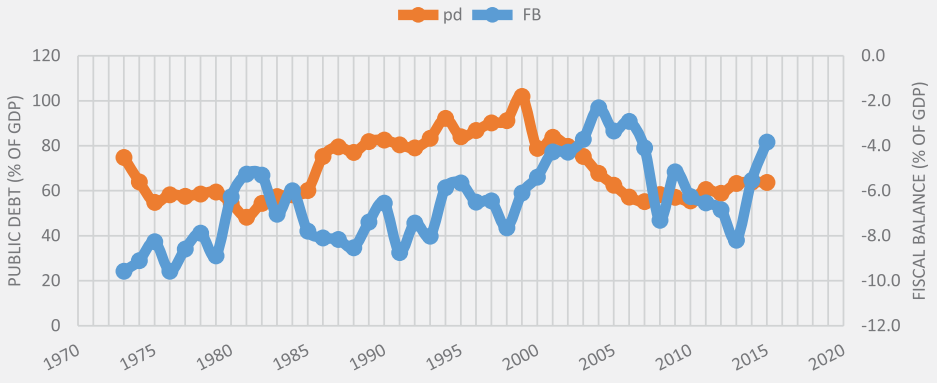


(Hyder, Akram and Padda, 2011). Pakistan fiscal balances are significantly better in 2014 than in 2013. Fiscal deficit further reduced in 2015 at 5.3\% of GDP, which slowed down the increasing trend of debt accumulation.

Graph 2 presents the trends in economic growth and public debt in Pakistan for the period of 1973-2018. There has been a negative relationship between GDP growth of Pakistan and public borrowing. This picture clearly indicates negative association between them in all periods that we have examined in our study. In this context, this study aims to explore the nonlinear relations with government borrowing and GDP growth of Pakistan.

The organization of the study is as follows: section 2 presents literature review, section 3 discusses materials and methods with theoretical review, empirical review, data collection techniques, section 3 covers the result and discussion, while the concluding section presents conclusion and implication emerging from this study.

\section{Review of Literature}

\section{Graph 2: Trends in economic growth rate and public debt in Pakistan}

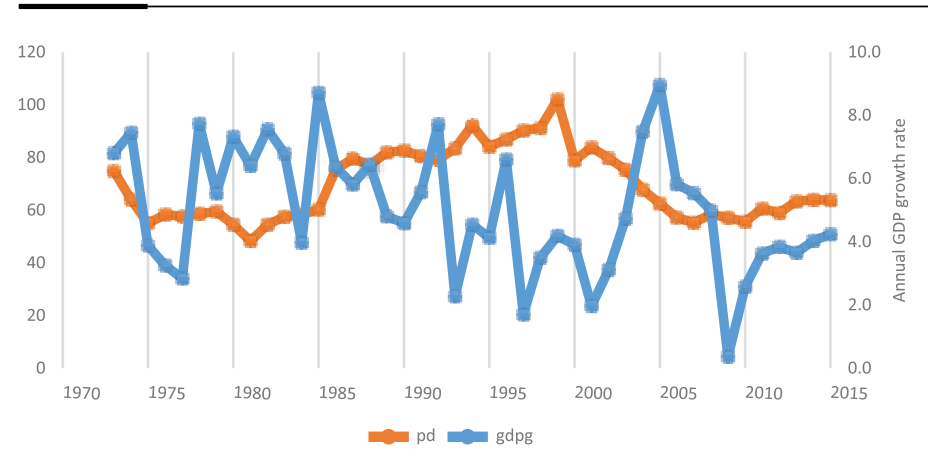

Note: Public debt is at primary axis while annual GDP growth rate is at secondary axis.

The theoretical models of GDP growth suggest that public debt has a crowding out effect when it is not properly utilized. In literature, many studies show adverse effects of the public debt on GDP (Saint-Paul, 1992; Aizenman et al., 2007). Many studies based on endogenous growth theories show positive impact of public debt on growth (Aizenman et al., 2007). A few studies have also presented a positive impact of public debt up to certain level (Aschauer, 2000). The empirical works on the non-linear association between government debt and GDP growth is limited, but are gaining importance in developed and developing economies.

Mupunga and Le (2015) have find out the growth maximizing level of public debt and have depicted that 80 percent is the percentage of GDP borrowing that is growth maximizing for Zimbabwe. Pham et al. (2014) empirically explores the optimal level of government debt in 15 developing countries. The empirical results explain that borrowing has positive influence on GDP between 13 to 39 percent of GDP. However, afterwards that debt can negatively affect growth. Presbitero (2012) has inspected the public liability and per capita growth in underdeveloped economies for selected time from 1990 to 2007, on panel study. The study 
finds that public borrowing negatively influences economic growth when it reaches 90 percentage of GDP, after that its effect becomes irrelevant.

Cristina and Philipp (2012) investigate the inverted U-shaped association of government borrowing on GDP per capita in twelve European countries, for the period of 40 years. The U-shaped association indicates that government borrowing maximizes growth until it reaches 80 percent of gross domestic product. Stephen et al. (2011) has empirically examined the debt turning points for organizations of economic corporations and developing countries. The results show that debt threshold level is around 85\% of GDP. The empirical results also depict that corporate debt has negative influence on GDP, when it reaches 90\% of GDP. Patillo et al. (2002) investigate how borrowing influences GDP growth indirectly through capital accumulation and total factor productivity in 61 emerging economies. They have investigated the presence of nonlinearities in debt on various sources of growth. On average, in high borrowing countries, output growth reduces $1 \%$ due to doubling the debt and reduces both capital accumulation and total factor productivity somewhat less than that.

Based on gap of available literature, present study concludes that there is limited literature in Pakistan that estimates the optimal level of growth maximizing public debt. Therefore, the main objective of this study is to find out growth maximizing optimal level of debt for Pakistan. Nonlinear estimation is commonly used to find out optimal level. This study also applies nonlinear estimation strategy by adding quadratic term of public debt (Cristina \& Philipp, 2012). We also aim to recognize the growth maximizing level of debt for economic growth. The time period for the study is 1973 to 2018.

\section{Research Method}

The present study examines empirically non-linear impact of government debt on economic growth of Pakistan. The selected growth model uses quadratic equation that relates to public borrowing and GDP growth. As investment and population growth are the main variables of any growth model. Public debt is introduced as a part of additional capital as present study aims to find out optimal level of debt. For this purpose, square terms of government debt are included in the model (Cristina \& Philipp, 2012; Jernej, Aleksander, \& Miroslav, 2015). Other controlled variables i.e. tax revenue (for fiscal policy), real interest rate (for monetary policy), openness, exchange rate (for competitiveness) are also parts of the model.

The basic estimation equation of the study is as follows:

$\mathrm{Gt}=\gamma_{\mathrm{o}}+\gamma_{1} \mathrm{PDt}+\gamma_{2} \mathrm{PD}_{\mathrm{t}}^{2}+\gamma_{3} \mathrm{gfcf}_{\mathrm{t}}+\gamma_{4} \mathrm{~N}_{\mathrm{t}}+\mathrm{X}_{\mathrm{t}}+\mu_{\mathrm{t}}$

Where $\mathrm{G}$ indicates economic growth, PD shows borrowing as \% of GDP, $\mathrm{PD}^{2}$ square of public debt, $\mathrm{N}$ population growth rate, $\mathrm{X}$ is vector of other control variables and $\mu$ is an error term.

\section{Data and Sources}

The present study uses annual data from 1973 to 2018, drawn from national and international sources. In national sources, most of the data are taken from statistical handbook published by State Bank of Pakistan, while international resources are World Development Indicators (WDI, 2016), World Bank database and International Financial Statistics. 


\section{Data Analysis and Result}

The descriptive statistics indicate minimum growth rate of $0.36 \%$ per annum, maximum of 8.95\% and an average of $4.9 \%$ growth remained during the sample period. The borrowing as percentage of GDP averaged at $69.88 \%$. The maximum and minimum value of public debt remained at $102 \%$ and $48 \%$ of GDP, respectively.

Table 1: Descriptive Statistics for Pakistan

\begin{tabular}{|l|r|r|r|r|r|}
\hline Variable & Mean & Median & Max & Mini & S.Dev. \\
\hline GDPG & 4.92 & 4.65 & 8.95 & 0.36 & 1.99 \\
\hline PD & 69.8 & 63.8 & 102 & 48.3 & 13.6 \\
\hline TT_R & 15.38 & 15.78 & 18.55 & 9.79 & 1.94 \\
\hline N & 2.59 & 2.50 & 3.34 & 2.02 & 0.49 \\
\hline TOP & 33.58 & 33.57 & 38.9 & 27.7 & 2.93 \\
\hline TFP & 0.98 & 0.96 & 1.31 & 0.65 & 0.18 \\
\hline L_IR & 9.628 & 9.335 & 13.36 & 3.41 & 2.64 \\
\hline GFCF & 16.34 & 16.96 & 19.23 & 12.52 & 1.63 \\
\hline
\end{tabular}

Time series data are often non-stationary and in case of non-stationary in variables ordinary least square (OLS) estimation becomes spurious. Thus, to avoid spurious results, this study applies unit root test to check whether every variable is stationary or not. The following section presents unit root test results.

\section{Unit Root Test}

The Augmented Dicky Fuller (ADF) results show that there is a mixture of level stationary I(o) and first difference stationary I(1) variables at 5\% level of significance. According to econometric theory, when the variables in model are integrated at level I(o) and first difference I(1) then Auto-Regressive Distributive Lab (ARDL) is the best approach to estimate the model which is proposed by Pesaran et al. (2001). Huag (2002) has claimed that ARDL method of co-integration gives better results than traditional methods to co-integration in a small sample size of data, which is only 43 in our case. Narayan (2005) has presented critical values of the F-Test for smaller data size with 30 to 80 observations.

Table 2: ADF unit root test results

\begin{tabular}{|c|c|c|c|c|c|c|c|}
\hline \multirow[b]{2}{*}{ Variable } & \multicolumn{3}{|c|}{ Level } & \multicolumn{3}{|c|}{ First difference } & \multirow[b]{2}{*}{ Decision } \\
\hline & Intercept & Trend and Intercept & None & Intercept & Trend and intercept & None & \\
\hline GFCF & -2.66 & $-3.46^{* *}$ & ----- & ------ & --------- & -------- & $\mathrm{I}(\mathrm{O})$ \\
\hline $\mathrm{PD}$ & -1.53 & -1.52 & -0.54 & $-7.15^{*}$ & ---------- & --------- & $\mathrm{I}(1)$ \\
\hline PDD & -1.66 & -1.64 & -0.81 & $-7.95^{*}$ & ----------- & -------- & $\mathrm{I}(1)$ \\
\hline TFP & -0.30 & -2.88 & 2.46 & $-4.40^{*}$ & ------------ & --------- & $\mathrm{I}(1)$ \\
\hline TT_R & -0.92 & -2.52 & -0.81 & $-5.74^{*}$ & ---------- & -------- & $\mathrm{I}(1)$ \\
\hline L_IR & $-3.59^{*}$ & -------- & -------- & |---------- & ---------- & -------- & $\mathrm{I}(\mathrm{o})$ \\
\hline TOP & $-3.00^{* *}$ & --------- & --------- & ------------ & ------------ & --------- & $\mathrm{I}(\mathrm{o})$ \\
\hline GDPG & $-4.50^{*}$ & --------- & --------- & ----------- & ----------- & --------- & $\mathrm{I}(\mathrm{o})$ \\
\hline
\end{tabular}




\begin{tabular}{|l|r|r|r|r|r|r|r|}
\hline $\mathrm{N}$ & -1.43 & $-3.74^{* *}$ & -------- & --------- & --------- & -------- & I(o) \\
\hline
\end{tabular}

\section{Co-integration Estimation}

The General form of ARDL vector error correction model for this study can written as:

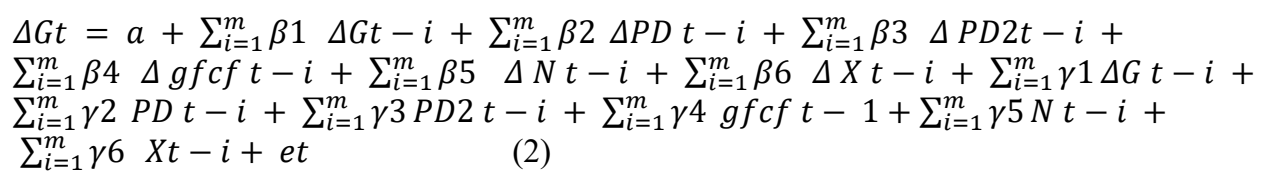

Here $\mathrm{a}$ is an intercept; $\beta \mathrm{s}$ are short run dynamic coefficients and $\gamma$ s are long run multipliers. The ARDL technique starts with the bound test. The null hypothesis of the bound test statistics here is not co-integration, and the alternative is co-integration as mentioned by Pesran et al. 2001. We have used four techniques for selection of optimal lag length. Table 3: Lag Length Selection Test

\begin{tabular}{|l|r|r|r|r|}
\hline Lag & \multicolumn{2}{|l|}{$\begin{array}{l}\text { Final prediction } \\
\text { error(FPE) }\end{array}$} & $\begin{array}{l}\text { Akaike information } \\
\text { criterion (AIC) }\end{array}$ & \multicolumn{2}{l|}{$\begin{array}{l}\text { Hannan-Quinn information } \\
\text { criterion (HQ) }\end{array}$} & $\begin{array}{l}\text { Schwarz information } \\
\text { criterion (SIC) }\end{array}$ \\
\hline o & 3.73257 & 4.14823 & $4.28471^{*}$ & $4.52059^{*}$ \\
\hline 1 & 3.9123 & 4.19268 & 4.34433 & 4.60642 \\
\hline 2 & 3.84623 & 4.17247 & 4.33929 & 4.62758 \\
\hline 3 & $3.71305^{*}$ & $4.13337^{*}$ & 4.31535 & 4.62985 \\
\hline
\end{tabular}

Table4: Bound test for co-integration

\begin{tabular}{|r|r|r|r|r|}
\hline \multirow{2}{*}{ F statistic value } & \multirow{2}{*}{ Lag length } & Significance level & \multicolumn{2}{|c|}{$\begin{array}{c}\text { Bound Critical } \\
\text { Values }\end{array}$} \\
\cline { 3 - 5 } & & & $\mathrm{I}(\mathrm{o})$ & \multicolumn{1}{|c|}{$\mathrm{I}(\mathrm{I})$} \\
\hline \multirow{3}{*}{5.78} & \multirow{2}{*}{3} & $10 \%$ & 1.95 & 3.06 \\
\cline { 3 - 5 } & & $5 \%$ & 2.22 & 3.39 \\
\cline { 3 - 5 } & & $1 \%$ & 2.79 & 4.1 \\
\hline
\end{tabular}

The bound test results show that the value of F-statistic value is 5.78 , which is higher than the critical $1 \%$ level of significance. The study used four criteria for lag length selection FPE, AIC, HQ and SIC. The suggested lag length is 3 and it is optimal for this model. Therefore, with the help of bound test value, we can conclude that there exists co-integration among the variables and long run and short run coefficients can be estimated.

\section{Long run and short run results}

Bound test confirms co-integration for the model. The long run coefficient results confirm statistically significant effects of borrowing and economic growth in Pakistan. Table 4 shows that public debt in linear form is positively co-integrated with growth in the long run in Pakistan, while public debt in a square form has negative and effect on GDP growth. It clearly indicates that if government borrowing increases, it will raise economic growth in Pakistan. After a certain level of further increase in government debt, it drags the economic growth. Intuitively, these results indicate that in economy of Pakistan public borrowing has an optimal level. Moreover, controlled variables like population growth (N), trade openness (TOP), to- 
tal factor productivity (TFP) and investment (GFCF) are directly co-integrated with growth. The trade openness result supports the view that free trade stimulates growth (Felipe et al., 2010). Long run estimation results also show that total tax revenue and long-term interest rates are co-integrated with economic growth adversely.

Table 5: Long Run and Short Run Estimation Results

\begin{tabular}{|c|c|c|c|c|c|}
\hline \multicolumn{3}{|c|}{$\begin{array}{l}\text { Long Run Estimates } \\
\text { Dependent Variable: GDPG } \\
\text { ARDL lag selection }(2,0,0,2,2,2,2,2,2)\end{array}$} & \multicolumn{3}{|c|}{$\begin{array}{l}\text { Short Run Estimates } \\
\text { Dependent Variable: GDPG } \\
\text { ARDL lag selection }(2,0,0,2,2,2,2,2,2)\end{array}$} \\
\hline Variable & Coefficient & t-Stat & Variable & Coefficient & t-Stat \\
\hline $\mathrm{PD}$ & $0.20^{*}$ & 2.74 & $\mathrm{D}(\mathrm{GDPG}(-1))$ & $0.35^{*}$ & 2.82 \\
\hline $\mathrm{PD}^{2}$ & $-0.0009^{* *}$ & -2.04 & $\mathrm{D}(\mathrm{PD})$ & $0.51^{*}$ & 2.67 \\
\hline TT_R & $-0.96^{*}$ & -4.64 & $\mathrm{D}\left(\mathrm{PD}^{2}\right)$ & $-0.002^{* *}$ & -2.04 \\
\hline $\mathrm{N}$ & $5.36^{*}$ & 8.99 & D(TT_R) & $-0.98^{*}$ & -4.66 \\
\hline TOP & $0.51^{*}$ & 5.67 & $\mathrm{D}$ (TOP) & $0.48^{*}$ & 5.03 \\
\hline TFP & $5.25^{*}$ & 4.67 & $\mathrm{D}(\mathrm{N})$ & 100.8 & 5.39 \\
\hline RI & $-0.45^{*}$ & -8.06 & D(TFP) & $37.70^{*}$ & 4.22 \\
\hline GFCF & $0.21^{* *}$ & 2.13 & $\mathrm{D}(\mathrm{RI})$ & $-0.20^{*}$ & -3.01 \\
\hline $\mathrm{C}$ & $-25.22^{*}$ & -7.94 & $\mathrm{D}(\mathrm{GFCF})$ & 0.30 & 1.01 \\
\hline D.W stat & 2.32 & & $\operatorname{ECM}(-1)$ & $-2.48^{*}$ & -8.93 \\
\hline F-stat & 11.71 & & $\mathrm{R}^{\wedge} 2$ & $0.94^{*}$ & \\
\hline
\end{tabular}

The last phase in ARDL technique is to examine error correction term and estimation of short run coefficients. Econometric theory suggests that if variables are co-integrated in a long run then errors are corrected in the short run and error correction (ECM) will also happen in the short run. The ECM has the ability to correct any disequilibrium that may come from any shock in the system from period to period. The ECM value defines the speed of adjustment. Table 4 shows that the ECM value is negative and significant. It shows that any shock or policy effect will be correct before the period of one year. Some of researchers suggest that ECM coefficient should be between $\mathrm{o}$ and 1 but in negative. It is still debatable. The authors' estimated coefficient is -2.48. However, Atique and Malik (2012) also suggested that ECM value can be more than -1 in absolute terms.

The short run coefficients also show that public borrowing has significant quadratic association with economic growth in Pakistan. In the short run, if public debt increases it will boost economic growth after some levels of public debt it will decline. Other variables in short runs, namely population growth, trade openness and total factor productivity, have direct effect on GDP growth. However, total revenue and long-term interest rate have negative impacts. In the short run, investment has positive but insignificant association with economic growth. ARDL results support our hypothesis that government debt has inverted U-shaped, association with growth both in the short run, as well as, in the long run.

\section{Optimal level of public debt for economic growth of Pakistan}

A quadratic form of model has been estimated to find out the optimal level of borrowing for economic growth of Pakistan. The ARDL results support to determining the optimal level of borrowing until which public debt enhances the GDP growth. After optimal level, further increment will lead to decline in growth.

Determination of optimal level of debt, the turning points through quadratic equation is done by; 
$\mathrm{GDP}=0.17 \mathrm{PD}-0.001 \mathrm{PD}^{2}$

Graph 3 is drawn on the basis of the above equation. It depicts that economy of Pakistan can increase growth until borrowing remain below 60 percent of GDP. The results are in line with Fiscal Responsibility and Debt Limitation Act (FRDL) 2005of Pakistan.Padda and Akram (2009), Padda (2010) and Padda (2014). It is assumed that the past offers reasonable guidelines for future, 60\% of GDP range of public debt could be considered as an optimal growth maximizing debt rate for Pakistan. The findings of this study are similar to Cristina \& Philipp (2012) ${ }^{2}$ and Tahir, Shahnaz \& Hafiz (2009). ${ }^{3}$ It is also notable that the model also shows that with the optimal level of borrowing the growth can reach a maximum of $5.3 \%$ per annum. Thus, to boost the growth, government requires exploring more/other resources as well. It is notable here that this optimal level of debt is estimated on the assumption of "ceteris paribus". However, in real world it is difficult to control other variables so situation may be different with better economic environment.

\section{Stability Test}

The stability tests based on CUSUM and CUSUM square are presented in graph 4 . The reGraph 3: Optimal Level of Public Debt for Economic Growth of Pakistan

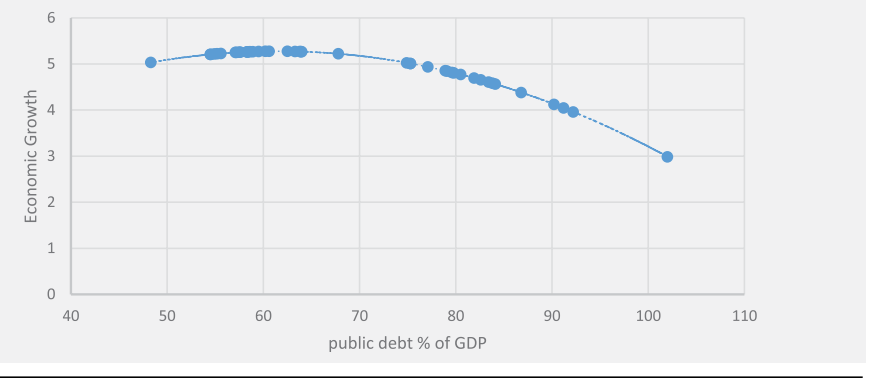

sults indicate that coefficient values lie within critical limits of $5 \%$ level of significance. This indicates the stability in the coefficient over the sample period.

Graph 4: CUSUM and CUSUM Square Test
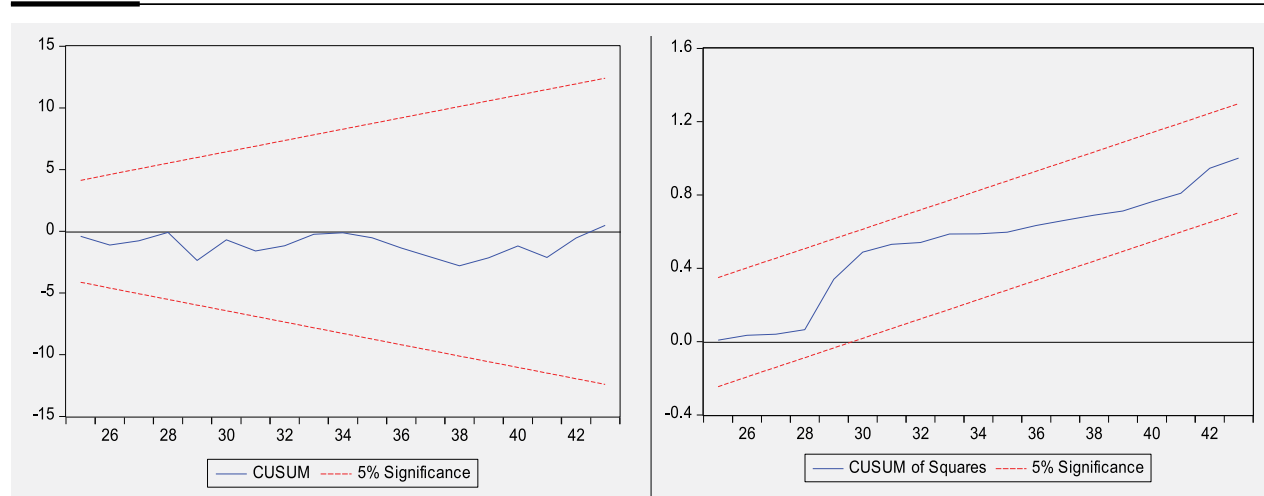


\section{Conclusion and Implications}

Public debt is considered detrimental for economic grwoth of a country when it exceeds the specific (optimal) level. This study explores the growth maximizing optimal level of debt for the economy of Pakistan. The results depict the significant dependence of economic growth on public debt. The study uses suitable estimation technique to find the results. The study finds that burrowing 60\% of GDP is the optimal level of government debt (growth maximizing debt). This depicts that borrowing more than 60\%of GDP will reduce economic growth in the long run. The growth maximizing level of borrowing in Pakistan indicates that the current level of debt (64\% in 2016) was slightly above the optimal level (60\% of GDP). So, the government should reduce borrowing to reach the optimal growth otherwise further borrowing will adversely affect economic growth. The optimal threshold level, 60\% of GDP is fixed by Fiscal Responsibility and Debt Limitation Act 2005 (Authority, 2005). Another study conducted by Saira \& Tanveer (2016) has suggested 62\% of GDP to be the optimal level of debt for Pakistan.

The study suggests that public debt must be discouraged more than optimal level as burrowing beyond the optimal level debt will reduces growth. Secondly, the government should focus on budget and trade deficit which are the main causes of increasing public debt in Pakistan, because higher public debt is not good for economic growth. Third, suitable fiscal policy is needed to control the debt burden and to get rid off the Ponzi game of debt from Pakistan by strictly enforcing the Fiscal Responsibility and Debt Limitation Act 2005. Moreover, another important result shows that higher interest rate curbs economic growth, therefore, present policy of keeping high interest rate by the government should be revisited.

\section{Conflict of Interest}

Authors have declared that no conflicting interests exist.

\section{References}

Aizenman, J., K. Kletzer \& B. Pinto. (2007). Economic Growth with Constraints on Tax Revenues and Public Debt: Implications for Fiscal Policy and Cross-country Differences (NBER Working Paper No. 1275). Retrieved from National Bureau of Economic Research website: https://www.nber.org/papers/w12750

Akram, N. (2011). Impact of public debt on the economic growth of Pakistan. The Pakistan Development Review, 50:4, 1-24.

Antonio, A., \& Joao, T. J. (2012). Growth and productivity: The role of government debt. International Review of Economics and Finance, 384-407.

Aschauer, D. A. (2000). Do states optimize? Public capital and economic growth. The Annals of Regional Science, 34(3), 343-363.

Atique, R., \& Malik, K. (2012). Impact of domestic and external debt on the economic growth of Pakistan. World Applied Sciences Journal, 20(1), 120-129.

Authority, S. (2005). Fiscal Responsibility and Debt Limitation Act, 2005. ACT NO. VI 2005. Retrieved from http:// www.finance.gov.pk/frdla2005 amended 2016.pdf

Barro, R. J. (1979). On the determination of the public debt. The Journal of Political Economy, 940-971.

Burnside, C., M, E., \& Rebelo, S. (2001). Prospective deficits and the Asian currency crisis. Journal of Political Economy, 109 (6), 1155-97.

Cecchetti, S. G., Mohanty, M. S., \& Zampolli, F. (2011). The real effects of debt (BIS Working Paper No. 352). Retrieved from https://papers.ssrn.com/sol3/papers.cfm?abstract id=1946170

Chaudhary, M., \& S, A. (2001). Debt laffer curve for South Asian countries . The Pakistan Devlopment Review , 705-722. 
Cristina, C.W., \& Philipp, R. (2012). The impact of high government debt on economic growth and its channels: An emperical investigation for the Euro Area. European Economic Review, 56 (2012), 1392-1405, 1-14.

Diamond, P. A. (1965). National debt in a neoclassical growth model. The American Economic Review, 55(5), 11261150.

Elmendorf, D. W., \& Mankiw, N. G. (1999). Government debt. Handbook of macroeconomics, 1, 1615-1669.

Felipe, J., J.S.L. McCombie \& Naqvi, K. (2010). Is Pakistan's growth rate balance of payments constrained? Policies and implications for development and growth. Oxford Development Studies, 38(4), 477-96.

Gul, A. (2008). Pakistan's Public Debt: The shocks and aftershocks.

Haris, A. B., \& Mohammad, A. K. (2015). The impact of federal government debt levels on productivity growth in Malaysia. International Journal of Business, Economics and Law, 7(3), 2289-1552.

Haug, A. A. (2002). Temporal aggregation and the power of co integration tests: A Monte Carlo Study. Oxford Bulletin of Economics and Statistics, 64 (4), 399-412.

Hyder, S., \& Akram, N. \& Padda (2011). An appraisal of fiscal decentralization in Pakistan. Journal of Economics and Economic Education Research, 12(2), 13.

Jernej, M., Aleksander, A., \& Miroslav, V. (2015). Revisiting the role of public debt in economic growth: The case of OECD. Inzinerine Ekonomika-Engineering Economics,26(1), 61-66.

Modigliani, F. (1961). Long-run implications of alternative fiscal policies and the burden. Economic Journal, 71 (284), 730-755.

Mupunga, N, \& Le, P. R. (2015). Estimating the optimal growth-maximising public debt threshold for Zimbabwe. Southern African Business Review,19(3), 1-27.

Narayan, P. K. (2005). The saving and investment nexus for China: Evidence from cointegration tests. Applied economics, 37(17), 1979-1990.

Nhu, P. T. Q., Tung, L. T., \& Vy, N. T. (2016). Identify threshold in the relationship between public debt and economic growth: the case of developing countries, In Seminar paper VEAM [Word file]. Retrieved from http://veam.org/wp-content/uploads/2016/o8/78.-Le-Thanh-Tung.pdf

Padda, I. (2010). On Minimizing the Welfare Cost of Fiscal Policy: Pakistan's Case. Pakistan Journal of Applied Economics, 20, 77-99.

Padda, I. U. H. (2014). On minimizing the welfare cost of fiscal policy: evidence from South Asia. Quality \& Quantity, 48(3), 1553-1572.

Padda, I. U. H., \& Akram, N. (2009). The Impact of Tax Policies on Economic Growth: Evidence from South-Asian Economies. The Pakistan Development Review, 48(4), 961-971.

Pattillo, C. A., Poirson, H., \& Ricci, L. A. (2002). External debt and growth (No. 2002-2069). Retrieved from International Monetary Fund website: https://www.imf.org/external/pubs/ft/wp/2002/wp0269.pdf.

Pesaran, M. H. Shin, Y. \& Smith, R. J. (2001). Bounds testing approaches to the analysis of level relationships. Journal of Applied Econometrics, 16, 289-326.

Presbitero, A. F. (2012). Total public debt and growth in developing countries. European Journal of Development Research, 24(4), 606-626

Rosemary, T. C. (1993). The effects of debt burden on economic growth in heavily indebted develoing nations. Journal of Economic Development, 18(1), 1-12.

Saint-Paul, G. (1992). Fiscal policy in an endogenous growth model. Quarterly Journal of Economics, 107, 1243-1259.

Safdar, F., \& Padda, I. U. H. (2017). Impact of institutions on budget deficit: the case of Pakistan. NUML International Journal of Business \& Management, 12(1), 77-88.

Saira, S., \& Tanveer, U. I. (2016). Public debt and economic growth incorporating endogeneity \& non-linearity (S H Working Paper Series No. 11:2016, 1-24). Retrieved from http://www.nust.edu.pk/Institutions/Schools/ S3H/Research/Documents/Saira\%2oSaeed\%2011-2016.pdf

Salotti, S., \& Trecroci, C. (2016). The impact of government debt, expenditure and taxes on aggregate investment and productivity growth. Economica, 83(330), 356-384.

Tahir, M., Shahnaz, A. R., \& Hafiz, K. A. (2009). Public and external debt sustainabilty in Pakistan. Pakistan Economic and Social Review, 243-267.

Ward, H. P., Ricci, L. A., \& Pattillo, C. A. (2004). What Are the Channels Through Which External Debt Affects Growth? (No. 04/15). Retrieved from https://ideas.repec.org/p/imf/imfwpa/o4-15.html.

WDI. (2016). World Development Indicator. USA: World bank. Retrieved from http://datatopics.worldbank.org/ world-development-indicators/ 